\title{
Biological variation of immunological blood biomarkers in healthy individuals and quality goals for biomarker tests
}

\author{
Najib Aziz ${ }^{1 *}$ D, Roger Detels ${ }^{1,2}$, Joshua J. Quint ${ }^{1}$, David Gjertson ${ }^{3}$, Timothy Ryner ${ }^{1}$ and Anthony W. Butch ${ }^{4}$
}

\begin{abstract}
Background: Cytokines, chemokines, adipocytokines, soluble cell receptors, and immune activation markers play an important role in immune responsiveness and can provide prognostic value since they reflect underlying conditions and disease states. This study was undertaken to investigate the components of biological variation for various laboratory tests of blood immunological biomarkers.

Results: Estimates of intra-individual coefficient of variation $\left(\mathrm{CV}_{1}\right)$ and inter-individual coefficient of variation $\left(\mathrm{CV}_{\mathrm{G}}\right)$ were examined for blood immunological biomarkers. Biomarkers with $\mathrm{CV}_{1}<10 \%$ for both genders were CD3, CD4, and CD8 T-cells, serum levels of soluble cluster of differentiation 14 (sCD14), sCD163, and soluble glycoprotein 130 (sgp130). The $\mathrm{CV}_{1}$ for serum levels of adiponectin, interleukin-1 receptor antagonist (IL-1Ra), macrophage inflammatory protein 1 beta (MIP-1ß), soluble CD40 Ligand (sCD4OL), soluble interleukin-2 receptor alpha (sIL-2Ra), soluble interleukin-6 receptor (sIL-6R), soluble tumor necrosis factor receptor II (sTNF-RII), and tumor necrosis factor alpha (TNF-a) were between 11 and 20\%. Biomarkers with $\mathrm{CV}_{\mathrm{G}}<20 \%$ were CD3 T-cell, and serum concentrations of SCD14, SCD40L, and sgp130. The biomarkers with $\mathrm{CV}_{\mathrm{G}}>40 \%$ were adiponectin, IL-1ra, leptin, MIP-1 $\beta$, SCD163, and SIL-2Ra.

Conclusion: The biological variations of biomarkers have important monitoring value for longitudinal investigation and are essential for quality specification of tests that are performed in the laboratory. The $\mathrm{CV}_{1}$ was relatively small while $\mathrm{CV}_{\mathrm{G}}$ was comparatively large and mean values of each biomarker vary between subjects. The individuality of biomarkers significantly influences reference interval values. A majority of the biomarkers in this study had strong individuality and the result of each biomarker should be cautiously interpreted if using established reference interval values. Comparison of a patient's test result with previous ones may be more useful than the usage of conventional reference values.
\end{abstract}

Keywords: Chemokine, Cytokines, Immune activation, Interleukin, Soluble markers

\section{Background}

Immunological biomarkers such as serum cytokines, chemokines, adipocytokines, soluble forms of cell receptors, and immune activation markers can serve as surrogate markers for cellular activation and play an important role in the function of the immune system. Complex interactions between immune cells of the innate and adaptive immune systems are modified by the release of a variety of cell mediators that trigger inflammatory responses which help to eliminate and

\footnotetext{
* Correspondence: naziz@mednet.ucla.edu

${ }^{1}$ Department of Epidemiology, Fielding School of Public Health at University California Los Angeles (UCLA), 650 Charles E. Young Dr. South, Los Angeles, CA 90095-1772, USA

Full list of author information is available at the end of the article
}

destroy foreign antigens. They serve numerous functions within our immune system and interact with specific cell types that correspond with different stages of disease.

Changes in the levels of these biomarkers along with changes in lymphocyte subset activity can provide important prognostic value by reflecting underlying disease conditions [1-7]. Thus, it is essential to be able to detect laboratory and clinically relevant changes by accurately measuring those blood biomarkers, making them potentially beneficial for the monitoring, diagnosis, and follow up of various diseases.

Clinical usefulness of these biomarkers depends upon: 1) their ability to account for a significant portion of the disease being evaluated; 2 ) the ability to be accurately, reproducibly, and reliably measured; and 3 ) the availability 
of the assay for widespread application [8]. Since blood levels of immunological biomarkers differ widely between individuals based on their gender, age, and other factors, baseline concentrations of biomarkers should be established for healthy individuals. In addition, the suitable biomarkers should have a low temporal intra-individual variability in healthy subjects otherwise any significant changes might not necessarily reflect disease processes.

Biological variation (BV) is often the most important source of variation over time for certain biomarkers and marked changes can occur during the neonatal, childhood, puberty, menopause, and aging process. In addition, certain biomarkers have biological rhythms that can vary diurnally, monthly, or seasonally [9].

There are a limited numbers of studies that have examined the BV of immunological biomarkers and lymphocyte phenotype and a majority of published studies have only investigated the BV associated with clinical chemistry and hematological biomarkers [10].

In this study we evaluated the short term (six weeks) temporal intra-individual variation $\left(\mathrm{CV}_{\mathrm{I}}\right)$ and inter-individual variation $\left(\mathrm{CV}_{\mathrm{G}}\right)$ of commonly requested laboratory tests for immunological biomarkers of serum/plasma cytokines such as interleukin-1 beta (IL-1 $\beta)$, interleukin- 6 (IL-6), interleukin-12p70 (IL-12p70), interleukin-1 receptor antagonist (IL-1Ra), interferon gamma (IFN- $\gamma$ ), and tumor necrosis alpha (TNF- $\alpha)$; chemokines such as interleukin-8 (IL-8), macrophage inflammatory protein 1 alpha $(\mathrm{MIP}-1 \alpha)$ or CCL3, macrophage inflammatory protein 1 beta (MIP-1 $\beta$ ) or CCL4, and regulated upon activation normal T cell expressed and secreted (RANTES) or CCL5; adipocytokines such as adiponectin and leptin; blood soluble forms of cell surface receptors such as soluble cluster of differentiation (CD)14 (sCD14), soluble CD25 (sCD25) or IL-2R $\alpha$, soluble CD40 Ligand (sCD40L), soluble CD120b (sCD120b) or sTNF-RII, soluble CD126 (sCD126) or sIL-6R, soluble CD130 (sCD130) or sgp130, and soluble CD163 (sCD163); immune activation markers such as neopterin and $\mathrm{T}$ and $\mathrm{B}$ lymphocyte phenotype. The clinical and research significance for each biomarker is outlined in the Additional file 4.

The aim of our study was to gather more information about the $\mathrm{CV}_{\mathrm{I}}$ and $\mathrm{CV}_{\mathrm{G}}$ of the biomarkers in healthy individuals and influences of $\mathrm{CV}_{\mathrm{I}}$ and $\mathrm{CV}_{\mathrm{G}}$ on the population based reference values as well as setting quality specification goals for precision, bias, and total error allowable of laboratory tests for those markers.

\section{Results}

The mean serum concentration of five groups (cytokines, chemokines, adipocytokines, soluble cell receptors, and immune activation markers) of biomarkers and the mean percentage of each lymphocyte subset for twelve normal participants, along with coefficients of variation for analytical $\left(\mathrm{CV}_{\mathrm{A}}\right)$, intra-individual $\left(\mathrm{CV}_{\mathrm{I}}\right)$, and inter-individual $\left(\mathrm{CV}_{\mathrm{G}}\right)$ for six women, six men, and both genders are shown in Tables 1 and 2. Measured serum levels of IL-12p70 and MIP-1 $\alpha$ for all twelve participants were lower than the minimum detectable dose.

Biological variation (BV) is expressed as a percentage and intra-individual variation was relatively small while inter-individual was relatively large. Biomarkers with a $\mathrm{CV}_{\mathrm{I}}<$ $10 \%$ for both genders were the percentage of $\mathrm{CD}^{+}$, $\mathrm{CD}^{+}$, and $\mathrm{CD}^{+}{ }^{+} \mathrm{T}$-cells; and serum concentrations of sCD14, sgp130, and sCD163. The $\mathrm{CV}_{\mathrm{I}}$ for IL-1Ra, TNF- $\alpha$, MIP-1 $\beta$, adiponectin, sIL2R $\alpha$, sCD40L, sTNF-RII, and sIL6R ranged from 11 to $20 \%$.

Biomarkers with a $\mathrm{CV}_{\mathrm{G}}<20 \%$ were the percentage of $\mathrm{CD}^{+}$T-cells and serum concentrations of sCD14, sCD40L, and sgp130. Biomarkers with the most inter-individual variability $\left(\mathrm{CV}_{\mathrm{G}}>40 \%\right)$ were serum concentrations of IL-1Ra, MIP-1 $\beta$, adiponectin, leptin, sIL2R $\alpha$, and sCD163.

Women had higher $\mathrm{CV}_{\mathrm{I}}$ for 10 out of 18 serum biomarkers compared to men, while men had a higher $\mathrm{CV}_{\mathrm{G}}$ for 13 of 18 serum biomarkers. $\mathrm{CV}_{\mathrm{G}}$ was not calculable in men for IL-1 $\beta$, because the mean square of inter-individual was smaller than inter-individual (Table 1). The influence of biomarker individuality on conventional population reference values and interpretation of laboratory test results visualized by the mean and absolute range of each biomarker for the twelve healthy subjects is presented in Fig. 1 for IL-1 $\beta$ (A), IL-6 (B), IFN- $\gamma(\mathrm{C})$, IL-1Ra (D), TNF- $\alpha$ (E), IL-8 (F), MIP-1 $\beta$ (G), RANTES $(\mathrm{H})$, and $\mathrm{sCD} 14(\mathrm{I})$; in Fig. 2 for $\mathrm{sCD} 40 \mathrm{~L}(\mathrm{~A}), \mathrm{sCD} 163$ (B), sIL-6R (C), sIL-2R $\alpha$ (D), sTNF-RII (E), sgp130 (F), Adiponectin (G), Leptin $(\mathrm{H})$, and neopterin (I); and in Fig. 3 for CD4 (A), CD8 (B), CD19 (C), and CD56/16 (D).

The desirable quality specifications for imprecision and bias (\%), total error allowable at 95 and 99\%, and the indices of individuality and heterogeneity for each of the biomarkers based on biological variation are calculated and summarized in Tables 3 and 4.

In addition, the mean, median, and inter-quartile range (IQR) of the biomarkers were calculated for six male, six female, and both genders, and presented in Additional file 1: Table S1a and Table S1b.

The Spearman's correlation was assessed to determine the relationship among the 18 serum biomarkers and 5 lymphocyte phenotypes of 12 subjects with six visits (total of 71 observations for each marker). There were both positive and negative statistically significant $(p<0.05)$ correlation coefficients $(R)$ among the markers, ranging from very weak to strong as shown in Additional file 2: Table $\mathrm{S} 2$. The markers with strong positive rho $(\mathrm{r}=0.65, p=$ $0.0001)$ were serum levels of TNF- $\alpha$ and IL-1ra and markers with strong negative rho $(\mathrm{r}=-0.65, p=0.0001)$ 
Table 1 Mean value of biomarkers, analytical $\left(C V_{A}\right)$, intra-individual $\left(C V_{1}\right)$, and inter-individual $\left(C V_{G}\right)$ components of variation for eighteen serum biomarkers

\begin{tabular}{|c|c|c|c|c|c|c|c|c|c|}
\hline & & Weighted & & $C V_{1}(0)$ & & & $C V_{G}(\%$ & & \\
\hline & Biomarker (unit) & Mean & $C V_{A}(\%)$ & Male & Female & Both & Male & Female & Both \\
\hline Group I & $\mathrm{IL}-1 \beta(\mathrm{pg} / \mathrm{mL})$ & 0.157 & $4.0^{\mathrm{a}}$ & 38.0 & 22.0 & 30.9 & $N C^{b}$ & 42.0 & 27.0 \\
\hline & $\mathrm{IL}-6(\mathrm{pg} / \mathrm{mL})$ & 0.961 & 6.4 & 23.0 & 20.0 & 21.5 & 33.0 & 19.0 & 26.4 \\
\hline & IL-1Ra (pg/mL) & 419.0 & 6.0 & 15.0 & 17.3 & 17.0 & 42.0 & 37.7 & 43.0 \\
\hline & $\mathrm{IFN}-\mathrm{\gamma}(\mathrm{U} / \mathrm{L})$ & 278 & 13.5 & 29.0 & 34.0 & 31.0 & 10.8 & 33.0 & 22.0 \\
\hline & TNF-a (pg/ml) & 12.63 & 8.2 & 7.9 & 14.2 & 12.7 & 24.3 & 31.7 & 27.2 \\
\hline Group II & $\mathrm{IL}-8(\mathrm{pg} / \mathrm{mL})$ & 12.16 & $3.5^{\mathrm{a}}$ & 24.0 & 61.6 & 51.4 & 32.0 & 28.0 & 30.2 \\
\hline & MIP-1 $\beta(p g / m L)$ & 101.0 & 4.5 & 18.0 & 22.0 & 20.0 & 22.0 & 82.0 & 57.0 \\
\hline & RANTES $(\mathrm{ng} / \mathrm{mL}))$ & 32.71 & 3.2 & 27.0 & 23.0 & 24.0 & 51.0 & 30.0 & 39.0 \\
\hline Group III & Adiponectin $(\mu \mathrm{g} / \mathrm{mL})$ & 6.29 & 3.7 & 12.0 & 17.0 & 15.9 & 49.0 & 42.0 & 48.1 \\
\hline & Leptin (ng/mL) & 7.66 & 7.1 & 18.0 & 31.0 & 31.0 & 66.0 & 50.0 & 68.0 \\
\hline Group IV & sCD14 (ng/mL) & 1435.0 & 2.8 & 8.8 & 7.6 & 8.0 & 16.0 & 6.1 & 11.4 \\
\hline & $\mathrm{sCD} 40 \mathrm{~L}(\mathrm{ng} / \mathrm{mL})$ & 6.02 & 3.0 & 14.5 & 12.7 & 13.2 & 18.4 & 12.8 & 14.6 \\
\hline & sCD163 (ng/mL) & 543.0 & 9.5 & 6.8 & 6.5 & 9.0 & 64.9 & 50.2 & 53.8 \\
\hline & sgp130 (ng/mL) & 281.0 & 4.8 & 4.4 & 7.5 & 7.0 & 12.5 & 10.4 & 15.0 \\
\hline & $\mathrm{sIL}-2 \mathrm{Ra}(\mathrm{pg} / \mathrm{mL})$ & 796.0 & 3.6 & 9.0 & 19.0 & 15.1 & 34.0 & 49.0 & 41.7 \\
\hline & sIL-6R (ng/mL) & 31.77 & $3.0^{\mathrm{a}}$ & 18.2 & 12.9 & 16.3 & 18.5 & 18.9 & 20.3 \\
\hline & sTNF-RII (ng/mL) & 2.17 & 10.1 & 17.6 & 15.8 & 17.4 & 36.0 & 25.9 & 28.9 \\
\hline Group V & Neopterin (nmol/L) & 5.20 & 6.4 & 14.5 & 64.0 & 35.0 & 69.4 & 14.0 & 37.0 \\
\hline
\end{tabular}

${ }^{\mathrm{a}}: \mathrm{CV}_{\mathrm{A}}$ calculated from 5 duplicated and two level assay control samples, ${ }^{\mathrm{b}}$ : not calculable (NC)

were serum levels of serum sIL-6R and $\mathrm{CD} 4^{+}$cells. The markers with weak positive rho $(r=0.24, p=0.043)$ were serum levels of sCD14 and MIP-1 $\beta$ and the markers with weak negative rho $(\mathrm{r}=-0.24, p=0.047)$ were serum levels of sCD14 and sIL-2R. The correlation for eight markers (rho and $p$ values), from strong correlation to no correlation, were depicted in Additional file 3: Figure S1 and Figure S2.

\section{Discussion}

Obtaining a reliable test result requires that all sources of variation should be minimized and components of biological variation $\left(\mathrm{CV}_{\mathrm{I}}\right.$ and $\left.\mathrm{CV}_{\mathrm{G}}\right)$ properly evaluated and managed during the entire process that leads to the final laboratory test report [11].

One of the eventual goals in the study of these biomarkers is to identify those with small biological variation, making them more appropriate for clinical use. It is not surprising that in healthy individuals, biomarker concentrations measured every six months for a period of five years are likely to display greater biological variation than biomarkers measured at a fixed time of the day for a period of 2 to 3 months [12].

The study was done based on the framework of the published study of Ford et al. [13]. Our study has some limitations due to the samples size of twelve participants and short period of follow up of six weeks which were

Table 2 Mean value lymphocyte phenotype, analytical $\left(\mathrm{CV}_{\mathrm{A}}\right)$, intra-individual $(\mathrm{CV})$, and inter-individual $\left(\mathrm{CV}_{\mathrm{G}}\right)$ components of variation for five lymphocyte phenotypes

\begin{tabular}{|c|c|c|c|c|c|c|c|c|}
\hline \multirow{2}{*}{$\begin{array}{l}\text { Biomarker } \\
\text { Phenotype }\end{array}$} & \multirow[t]{2}{*}{ Weighted Mean (\%) } & \multirow[t]{2}{*}{$C V_{A}(\%)$} & \multicolumn{3}{|c|}{$\begin{array}{l}\text { Intra-subject variation } \\
\mathrm{CV}_{\text {I }}(\%)\end{array}$} & \multicolumn{3}{|c|}{ Inter-subject variation $C V_{G}(\%)$} \\
\hline & & & Male & Female & Both & Male & Female & Both \\
\hline CD3 (T cells) & 73 & 1.0 & 3.0 & 4.1 & 3.6 & 8.3 & 13.6 & 10.8 \\
\hline CD4 & 46 & 3.2 & 6.8 & 5.6 & 6.1 & 10.5 & 20.9 & 20.7 \\
\hline CD8 & 25 & 2.4 & 6.9 & 5.7 & 6.7 & 20.3 & 43.6 & 35.5 \\
\hline CD19 (B cells) & 12 & 4.1 & 22.0 & 12.6 & 17.4 & 27.4 & 37.0 & 31.9 \\
\hline CD56/16 (NK cells) & 13 & 5.8 & 21.4 & 24.9 & 23.0 & 23.4 & 50.9 & 37.1 \\
\hline
\end{tabular}

$\mathrm{CV}_{\mathrm{A}}$ is analytical variation (mean $\mathrm{CV}$ of daily $\mathrm{QC}$ run for 20 days) expressed as a \%CV 

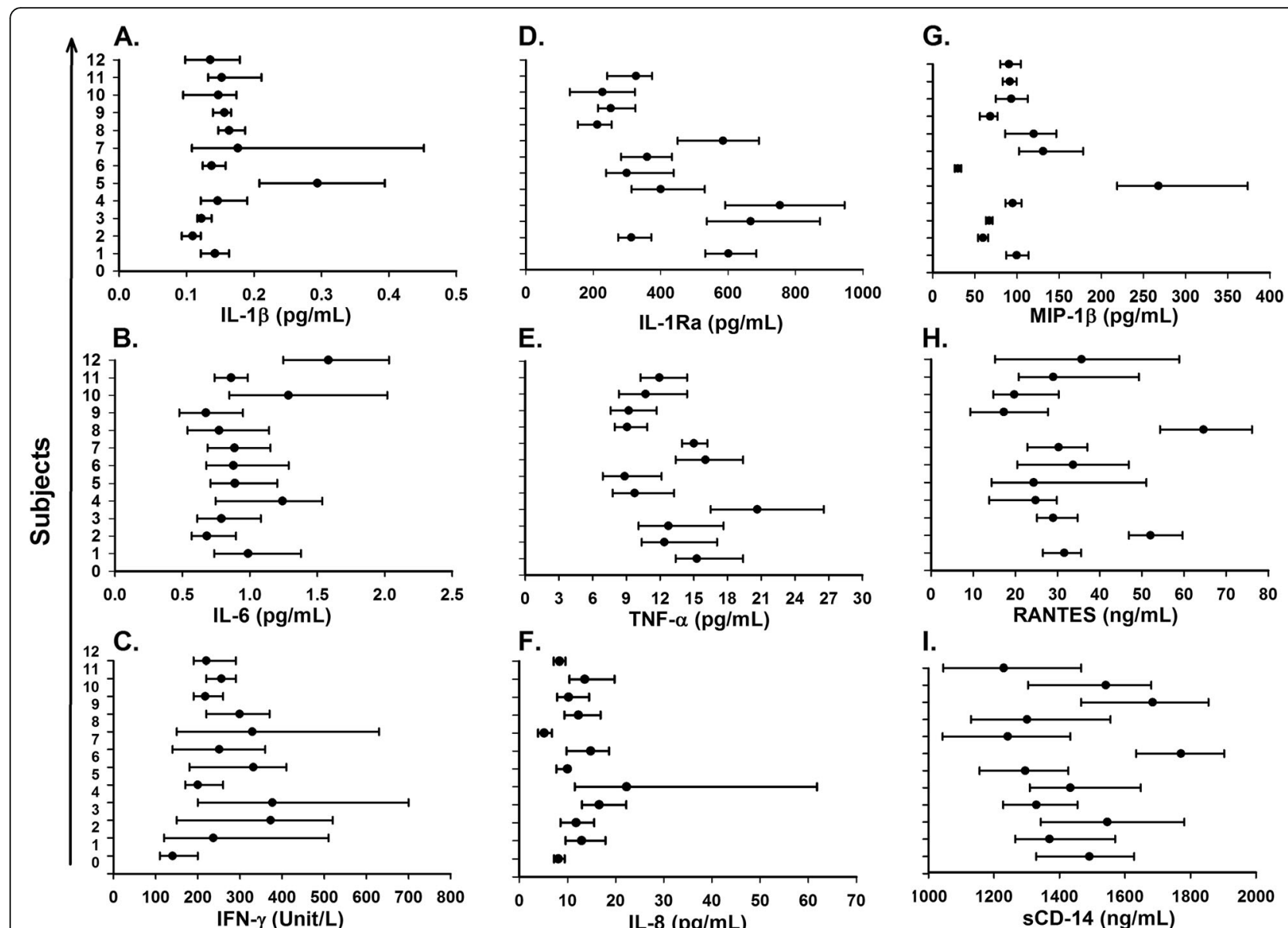

E.
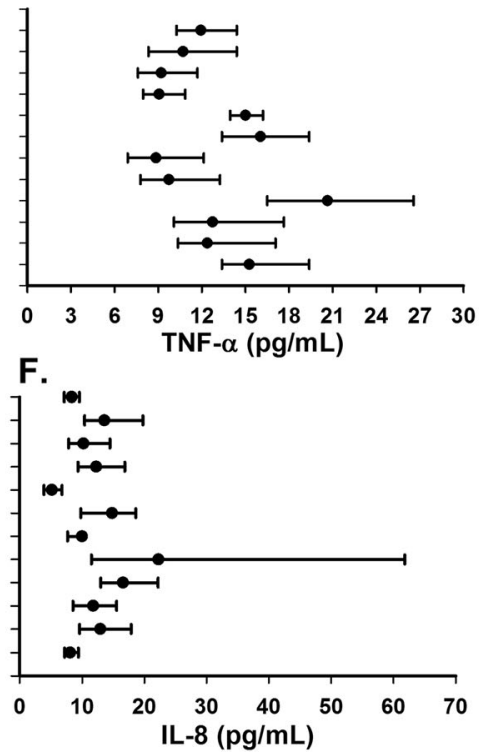

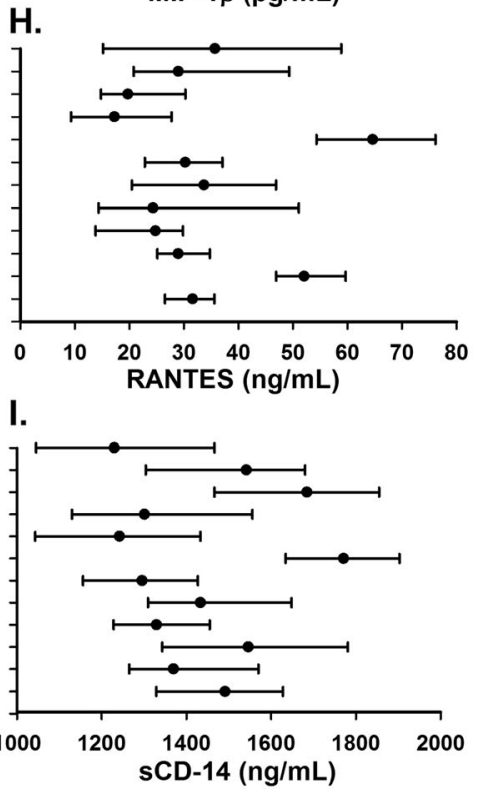

Fig. 1 Mean (filled circle) and absolute range (error bar) for each subject $(n=12)$ over six weeks, for serum level of IL-1 $\beta$ (a), IL-6 (b), IFN- $\gamma(\mathbf{c})$, IL1 Ra $(\mathbf{d})$, TNF-a (e), IL-8 (f), MIP-1 $\beta$ (g), RANTES (h), and SCD14 (i)

due to practical reasons of financial constraints and keeping all the participants throughout the entire study.

There is little data available regarding biological variability for many of the immunological biomarkers (7 out of 23) examined in this study. Our BV data will provide valuable information for improving the measurement and interpretation of blood biomarker levels examined in our study including setting quality specifications, distinguishing normal levels from those of a diseased state, assessing the usefulness of population-based reference values, selecting the best sample to collect, choosing the best test, validating a new testing procedure, and implementing an internal quality control procedure.

\section{Biological variation}

Available published data for $\mathrm{CV}_{\mathrm{I}}$ and $\mathrm{CV}_{\mathrm{G}}$ of immunological biomarkers are presented in Table 5 for comparison purposes [14-17]. Our intra- and inter-individual variation of adiponectin and IL- $1 \beta$ were nearly identical with published data, however there are differences in the intra- and inter-individual variation for other biomarkers compared to ours. Estimates of $\mathrm{CV}_{\mathrm{I}}$ and $\mathrm{CV}_{\mathrm{G}}$ should be comparable across all the studies but these differences may be due to the gender ratio, sample size, number of visits, as well as duration of each study.

Women had higher $\mathrm{CV}_{\mathrm{I}}$ for 10 out of 18 serum biomarkers compared to men and this could be due to menstrual cycle hormones induced changes. A weakness of the study is that we overlooked the possible influence of menstrual cycle phases' and this information was not collected from the female participants. There was no significant difference of $\mathrm{CV}_{\text {I }}$ for blood level of IL-6 reported during menstrual cycle [18] and marked fluctuations of blood levels of TNF-a reported in women [19]. In addition no significant changes reported in lymphocytes subsets over the course of a menstrual cycle [20].

Bear in mind that some of the analytes, notably IFN $-\gamma$ and IL- $1 \beta$, are conducted near the minimum detectable dose (MDD) of the assay and several healthy control and HIV-positive subjects of our previously study had plasma levels of markers below MDD. Thus, the low plasma levels of biomarkers may contribute to high CV [21]. 

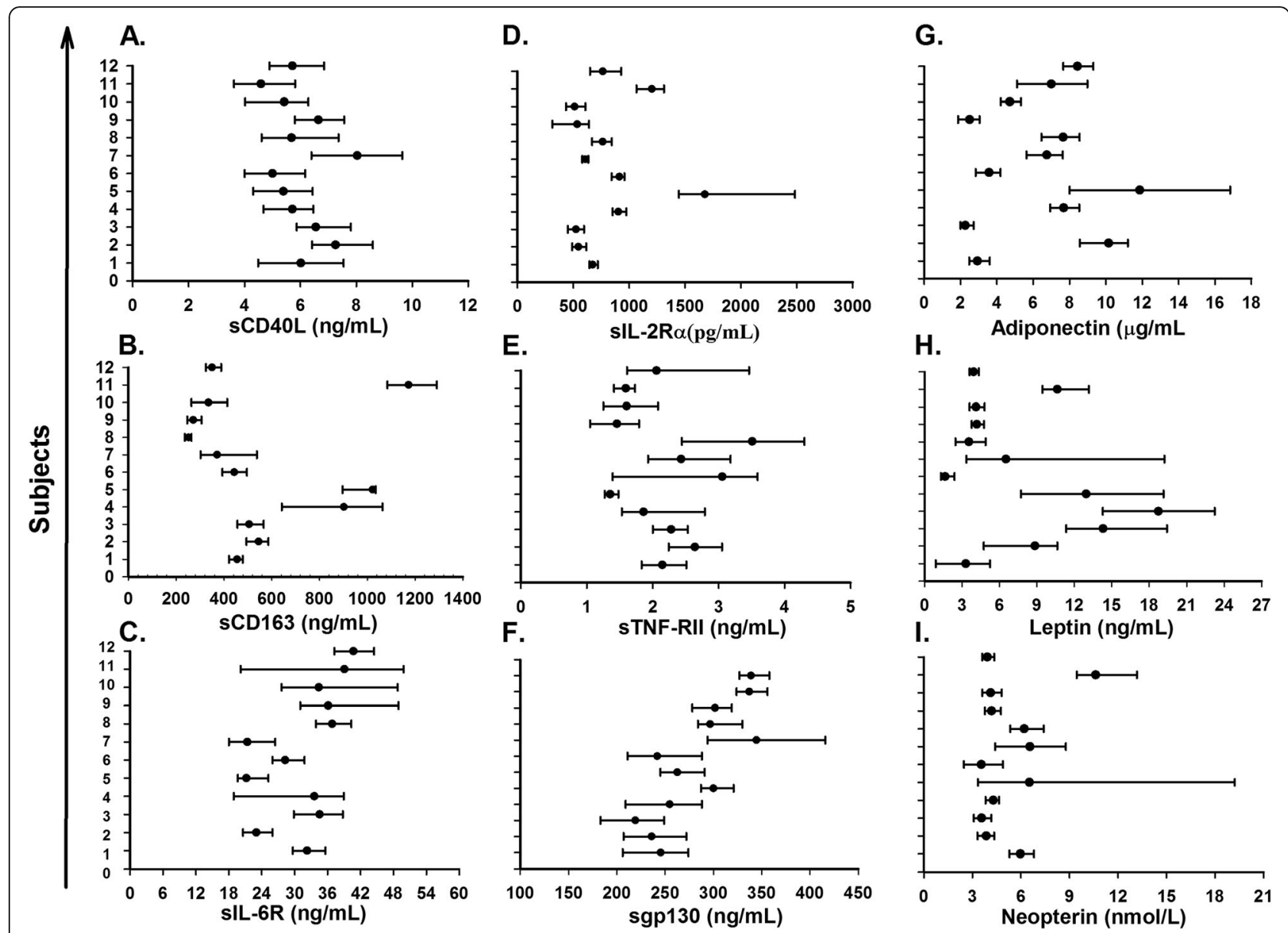

Fig. 2 Mean (fialled circle) and absolute range (error bar) for each subject ( $n=12)$ over six weeks, for serum level of SCD40L (a), sCD163 (b), sIL-6R (c), sIL-2Ra (d), sTNF-RII (e), sgp130 (f), Adiponectin (g), Leptin (h), and Neopterin (i)

\section{Setting analytical goals based on biological variation}

The desirable analytical imprecision goal for monitoring purposes has to be maintained at $\mathrm{CV}_{\mathrm{A}}<0.50 \mathrm{CV}_{\mathrm{I}}$ in order for the amount of variability that is added to true test results to be less than $12 \%$ (11.8\% calculated). Confidence in the precision of an assay allows us to run fewer internal quality control samples for the biomarker.

The analytical goal of imprecision of biomarkers based on BV are presented in Tables 3 and 4 and by comparing those data with the $\mathrm{CV}_{\mathrm{A}}$ obtained (Tables 1 and 2) for the biomarkers, we can conclude that, with exception of TNF- $\alpha$, sCD163, sgp130, sTNF-RII, and CD4 $4^{+}$T-cell, all other markers met the desirable analytical precision.

$\mathrm{CD}_{4}{ }^{+} \mathrm{T}$-cell, macrophage, and dendritic cells are vulnerable to human immunodeficiency virus type 1 (HIV-1) infection because of their CD4 receptor that the HIV-1 virus uses to infect those cells. The production of infectious virion from provirus requires activation of infected $\mathrm{CD}^{+}{ }^{+} \mathrm{T}$-cell and the $\mathrm{CD} 4^{+} \mathrm{T}$-cell count along with HIV viral load is an important monitoring laboratory tool for follow up of HIV-1 infected patients receiving treatment.
HIV-1 replicates especially in activated $\mathrm{CD}^{+} \mathrm{T}$ cell. However, at any given time, most of the $\mathrm{CD} 4^{+} \mathrm{T}$ cells in the HIV-1 infected individual are in resting status and not fully permissible for viral replication. In addition HIV-1 infected individuals receiving highly active antiretroviral therapy (HAART) showing suppression of viremia and activation of $\mathrm{CD} 4^{+} \mathrm{T}$ cells [22]. CD40L that expressed predominantly on activated $\mathrm{CD} 4^{+} \mathrm{T}$-cells and play multiple role in HIV-1 infection [23]. The blood levels $\mathrm{CD} 4^{+} \mathrm{T}$-cells and soluble $\mathrm{CD} 40 \mathrm{~L}(\mathrm{sCD} 40 \mathrm{~L})$ could be variable during stages of $\mathrm{CD} 4^{+} \mathrm{T}$-cell activation by HIV-1 or other infection, but have not seen variability in our normal study population.

The numerical goal for desirable bias is also calculated for each of the markers (Tables 3 and 4) and should be less than one quarter of the group biological variation. In a practical sense, the goal for desirable bias is achievable, but it will be problematic when using many different methods for the same assay. These biological variation data of immunological laboratory tests may solve many analytical problems for the assay. In addition, this would 
A.

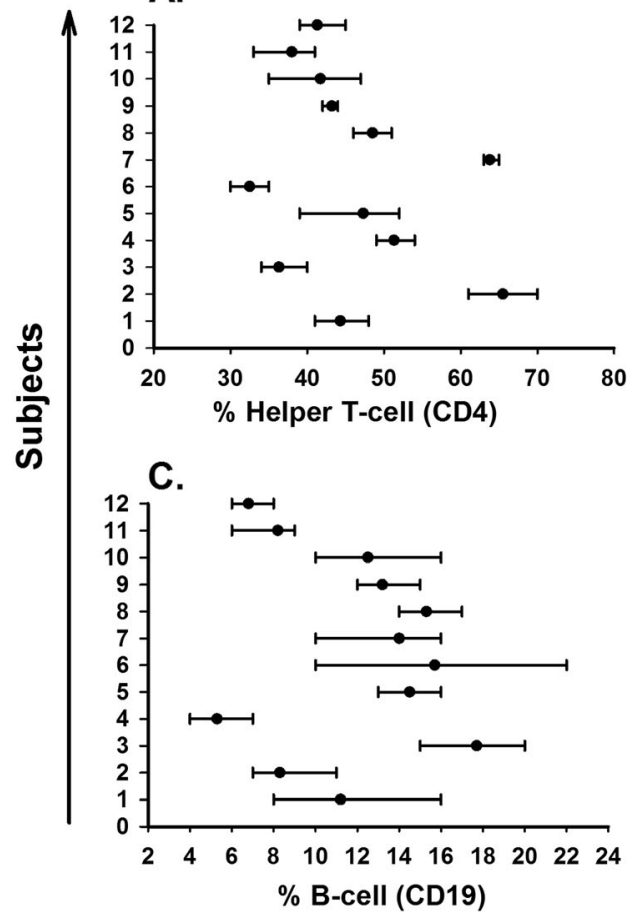

B.

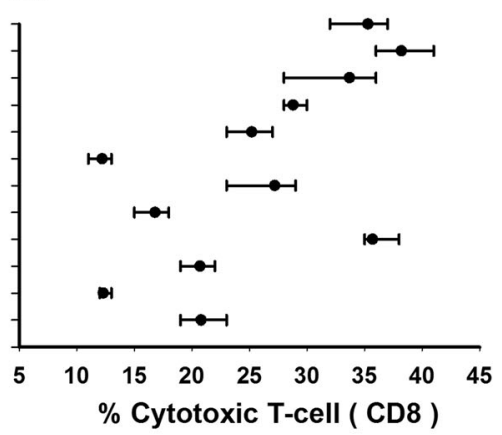

D.

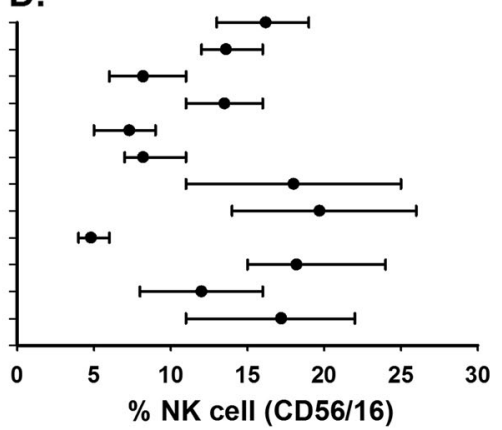

Fig. 3 Mean (filled circle) and percentage range (error bar) for each subject ( $n=12)$ over six weeks, for helper T-cell (a), Cytotoxic T-cell (b), B-cell (c), and NK cell (d)

provide objective analytical goals for manufacturers of instruments and assay kits [24].

\section{Reference change values}

For a disparity in serial test results to be significant, the difference in numerical results must be greater than the combined variation in the two serial results and this is referred to as the reference change value (RCV) [9].

Little intra-individual biological variation for blood immunological biomarkers has been published and laboratories need to determine their own biological variation for intra-individual in order to calculate the RCV. The 95\% probability $(p<0.05)$ for immunological biomarkers RCV is presented in Tables 3 and 4 and any differences between two successive quantity results exceeding the RCV for that biomarker should be further investigated [25].

\section{Utility of reference values}

It has well known that $\mathrm{CV}_{\mathrm{I}}$ is relatively small and mean value of each individual differ from each other and $\mathrm{CV}_{\mathrm{G}}$ relatively large and also our study illustrated the same pattern for the markers (Figs. 1, 2 and 3). The effect of index of individuality(I.I) of biomarkers on reference values were known and when I. I is less than 0.6, conventional population based reference values are limited in detection of unusual results in contrast when I. I is more than 1.4 [26]. The I. I with exception of IFN- $\gamma(\mathrm{II}=$
1.52) and IL-8 (II = 1.70) for all other biomarkers in our study were at or below 1.14.

All biomarkers in our study had an index of heterogeneity $(\mathrm{IH})$ of less than 1.58 which is an indication of the homogeneity of the collected specimen for within-subject biological variation. This value determines whether results obtained from a few subjects can be extrapolated to almost all subjects [24, 27].

\section{Choosing the best test}

Knowledge of the biological variation of biomarkers can help us to select the most appropriate test for tracking of disease progression or investigational purposes. In some cases, there may be multiple tests to accomplish the same goal, but one may be superior to the others and BV data can help choose which test to use. For example, serum sCD14, sCD163, and neopterin tests can all be used for the evaluation of macrophage activation and while none of these three tests have diagnostic value, they are useful for monitoring and follow up purposes. Soluble CD14 has a RCV of 23, less than both sCD163 and neopterin, making sCD14 a better monitoring test compared to the other two. However, when considering the ideal test to perform, one must also keep in mind that various stimulants may work on the target cells through different pathways and therefore each 
Table 3 Analytical goals for imprecision, bias, total error allowable $\left(\mathrm{TE}_{\mathrm{a}}\right)$ for $p<0.01$ and $p<0.05$, reference change value (RCV), Reliability coefficient (R), indices of individuality $(\mathrm{II})$, and index of heterogeneity $(\mathrm{IH})$ for eighteen serum biomarkers

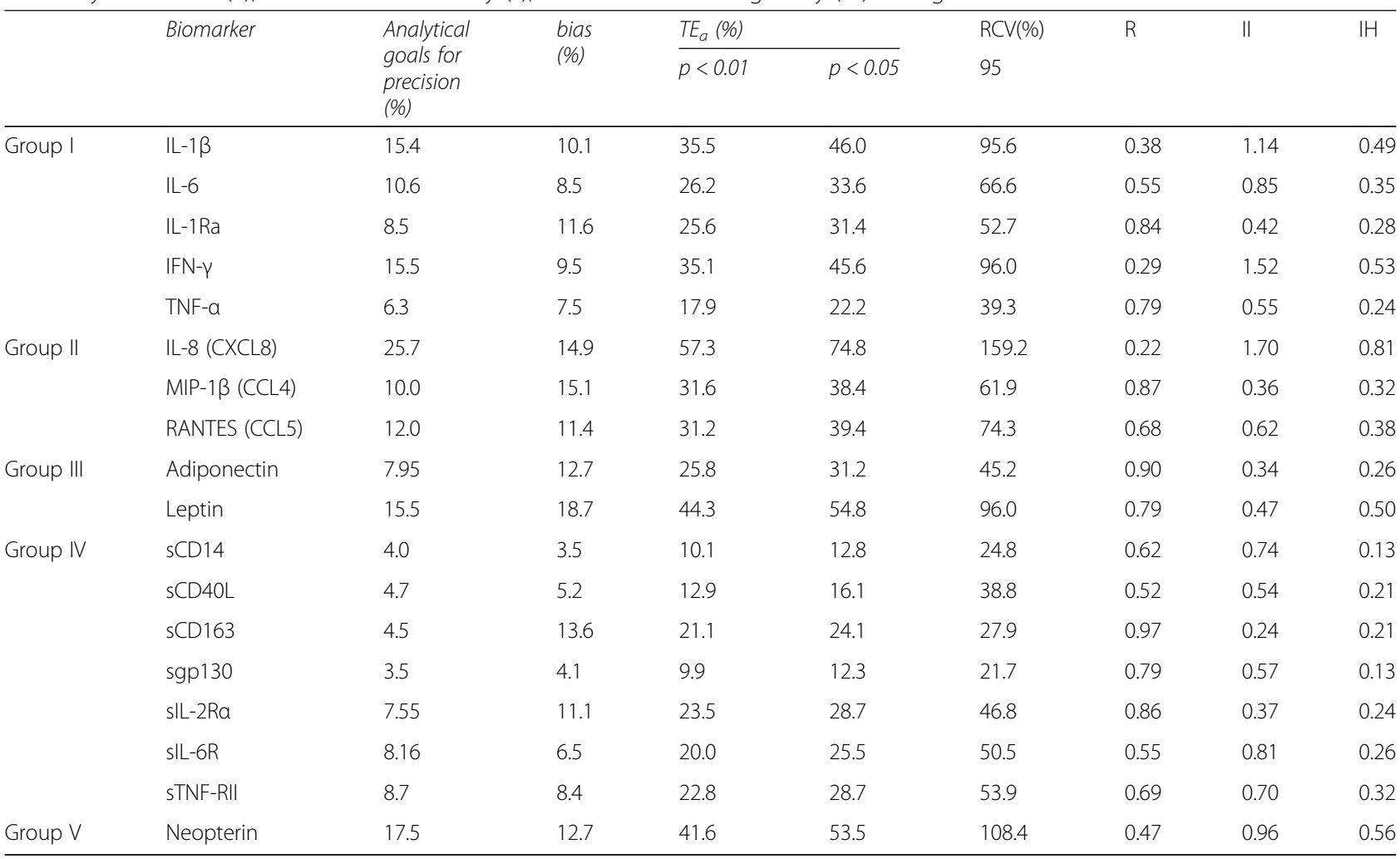

Group I represents cytokines, Group II is chemokines, group III is adipocytokines, group IV represents soluble cell receptors, and group V is immune activation markers

biomarker may provide different information about the disease progression.

\section{Conclusion}

The biological variation data generated by our study of 23 biomarkers is the first published data for 16 of the 23 biomarkers and will be valuable for clinical and laboratory use, particularly for setting quality specification goals for immunological biomarker testing purposes. The usefulness of BV data for healthy subjects is well documented for having utility in laboratory medicine.
Using serial samples to detect deviations in a patient that differ from those observed in healthy subjects can be a sign of analytic error or real biologic changes. These signals can then be looked into to avoid compromising patient care, or to further investigate the cause of the change [26]. Despite having a limited number of subjects in our study, we found intra-subject variation to be relatively small and inter-subject variation to be relatively large for the majority of biomarkers that were analyzed. In our study, most biomarkers had strong individuality, meaning that the result of a biomarker should be

Table 4 Analytical goals for imprecision, bias, total error allowable ( $\left.T E_{a}\right)$ for $p<0.01$ and $p<0.05$, reference change value (RCV), Reliability coefficient (R), index of individuality (II), and index of heterogeneity $(\mathrm{IH})$ for five lymphocyte phenotypes

\begin{tabular}{|c|c|c|c|c|c|c|c|c|}
\hline \multirow[t]{2}{*}{ Biomarker Phenotype } & \multirow{2}{*}{$\begin{array}{l}\text { Analytical } \\
\text { goal for } \\
\text { precision } \\
\text { (\%) }\end{array}$} & \multirow{2}{*}{$\begin{array}{l}\text { bias } \\
(\%)\end{array}$} & \multicolumn{2}{|l|}{$T E_{a}(\%)$} & \multirow{2}{*}{$\begin{array}{l}P C V(\%) \\
P<0.05\end{array}$} & \multirow[t]{2}{*}{$R$} & \multirow[t]{2}{*}{$\|$} & \multirow[t]{2}{*}{ 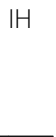 } \\
\hline & & & $p<0.05$ & $p<0.01$ & & & & \\
\hline CD3 (T cells) & 1.8 & 2.8 & 5.8 & 7.0 & 11.1 & 0.89 & 0.34 & 0.06 \\
\hline CD4 & 3.1 & 5.4 & 10.5 & 12.6 & 19.2 & 0.90 & 0.33 & 0.11 \\
\hline CD8 & 3.4 & 9.0 & 14.6 & 16.8 & 19.8 & 0.96 & 0.20 & 0.11 \\
\hline CD19 (B & 8.7 & 9.1 & 23.4 & 29.4 & 49.6 & 0.76 & 0.56 & 0.28 \\
\hline cells) CD56/16 (NK cells) & 11.5 & 10.9 & 29.9 & 37.7 & 65.7 & 0.71 & 0.64 & 0.37 \\
\hline
\end{tabular}


Table 5 Previous studies examining/reporting the intra-individual $\left(\mathrm{CV}_{l}\right)$ and inter-individual $\left(\mathrm{CV}_{\mathrm{G}}\right)$ variation of some biomarkers

\begin{tabular}{|c|c|c|c|c|c|c|}
\hline \multirow{2}{*}{$\begin{array}{l}\text { Biomarker } \\
\text { Adiponectin }\end{array}$} & \multicolumn{2}{|c|}{$\begin{array}{l}C V_{1}(\%) \\
\text { Pub. Our }\end{array}$} & \multicolumn{2}{|c|}{$\begin{array}{l}C V_{G}(\%) \\
\text { Pub. Our }\end{array}$} & \multirow{2}{*}{$\begin{array}{l}\text { Subject/ Visit/Period } \\
(6 m+6 f) /(6 v-6 w) \\
(7 m+15 f) /(2 v-15 m o)\end{array}$} & \multirow{2}{*}{$\begin{array}{l}\text { Reference } \\
\text { Shand et al. [14] }\end{array}$} \\
\hline & 18.8 & 15.9 & 51.2 & 48.1 & & \\
\hline$I L-1 \beta$ & 30.0 & 30.9 & 36.0 & 27.0 & $(4 m+11 f) /(6 v-6 m o)$ & Gonzalez et al. [15] \\
\hline IL-8 & 24.0 & 54.4 & 31.0 & 30.2 & $(4 m+11 f) /(6 v-6 m o)$ & Gonzalez et al. [15] \\
\hline IL-6 & 48.5 & 21.5 & 39.4 & 26.4 & $(4 m+11 f) /(6 v-6 m o)$ & Cava et al. [16] \\
\hline TNF-a & 43.0 & 12.7 & 29.0 & 27.2 & $(4 m+11 f) /(6 v-6 m o)$ & Gonzalez et al. [15] \\
\hline sIL-2Ra & 5.8 & 15.1 & 38.8 & 41.7 & $(4 m+11 f) /(6 v-6 m o)$ & Cava et al. [16] \\
\hline sCD163 & 9.0 & 15.9 & 35.9 & 48.1 & $(0 m+12 f) /(12 v-35 d)$ & Moller et al. [17] \\
\hline
\end{tabular}

$m$ male, $f$ female, $v$ visit, $w$ week, mo month, Pub published data, Our our data, $d$ day

cautiously interpreted if using an established reference values. In general, comparison of a patient's laboratory results with previous ones will be a better choice.

\section{Materiel and methods Specimens}

The study was approved by the institutional review board (IRB) for human studies at UCLA and informed consent was obtained from twelve self-reported healthy volunteers, including six men $(21,32,33,40,42$, and 51 years old, with weight of $175,190,165,178,172$, and $194 \mathrm{lbs}$. and body mass index (BMI) of 25.1, 26.5, 22.4, $27.1,26.9$, and 26.3 , respectively) and six women $(23,24$, $39,41,47,47$ years old, weight of 142, 123, 143, 139, 141 , and $140 \mathrm{lbs}$. and BMI of 24.4, 19.9, 22.4, 23.8, 24.2, and 24.0, respectively). The individuals all self-reported no health problems or menstrual cycle at the time of blood collection. Blood was collected into one $10 \mathrm{~mL}$ serum separator tube (SST) and one $4 \mathrm{~mL}$ vacutainer tube containing EDTA (Becton Dickinson Vacutainer System Franklin Lakes, NJ) to obtain serum and whole blood, respectively. Blood was collected according to the Clinical and Laboratory Standards Institute (CLSI) standard by phlebotomist between 9:00 am and 11:00 am (to prevent any circadian rhythm variation) once a week from the twelve subjects for a total of six weeks (subject \#11 missed visit \#4 of his blood draw). The SST blood tube from each individual was centrifuged within one hour after collection (500 $x \mathrm{~g}$ for $10 \mathrm{~min}$ ) and the serum was separated and frozen at $-70^{\circ} \mathrm{C}$ until batch analysis. EDTA whole blood was used to determine cell surface markers on lymphocytes by flow cytometry.

\section{Method of measurement}

Serum concentrations of each biomarker were determined using commercially available enzyme- linked immunosorbent assays (ELISA) and all serum samples of each individual were batched and tested in duplicate in a single assay (IL-1 $\beta$, IL-8, and sIL-6R tested singleton). The detailed instructions of each assay procedure are available through the manufactures' website and all the assays were performed according to the manufacturer's instructions. The MDD, intra-assay data of TNF- $\alpha$, IFN$\gamma$ and IL-12p70 and neopterin are from our lab (pool of serum) while the rest of the data is from the manufacturer (R\&D Systems) and the method of measurement for each biomarker is summarized in Table 6 while their clinical and research significance along with publication references for each biomarker is included as supplementary text in Additional file 4.

\section{Flow cytometry}

Flow cytometric analysis was performed using a FACSCalibur analyzer and CellQuest software (BDIS, San Jose, CA) [28]. In summary for each sample, $50 \mu \mathrm{l}$ of blood was stained with $\mathrm{BD}$ monoclonal antibodies conjugated with immunofluorescence such as fluorescein isothiocyanate (FITC) or phycoerythrin (PE), or Peridinin Chlorophyll Protein Complex (PerCP) or Allophycocyanin (APC), (BD Biosciences, San Jose, CA) using lyse no wash sample preparation method, with lymphocyte gating done according to the manufacturer's instructions. CD3-FITC, CD8$\mathrm{PE}, \mathrm{CD} 45-\mathrm{PerCP}$, and CD4-APC were used to label T cells in the first sample. In the second sample, CD3-FITC, CD56/16-PerCP, and CD19-APC monoclonal antibodies were used for identification of natural killer (NK) cells and $\mathrm{B}$ cells. The percentages of $\mathrm{CD}^{+} / \mathrm{CD}^{+}$(helper T-cell), $\mathrm{CD}^{+} / \mathrm{CD}^{+}$(cytotoxic T-cell), $\mathrm{CD}^{-} / \mathrm{CD} 56 / 16^{+}$(natural killer cell), and $\mathrm{CD}^{-} / \mathrm{CD} 19^{+}$(B-cell) cells were determined by flow cytometric analysis.

\section{Statistical analysis}

A four-parameter curve-fitting program was used for generation of calibration curves and computation of unknown concentrations of each biomarker. The SigmaPlot software (Jandel Scientific, San Rafael, CA, USA) package was used for all plots. STATA, version 14.23 (StataCorp LLC, College Station, Texas), was used for Spearman's correlation to assess the relationship among serum levels and cell surface markers. SAS, version 9.3 (SAS Institute, Inc., 
Table 6 Suppliers of biomarker assays, minimum detectable dose (MDD), Intra-assay coefficient of variation (CV \%), and mean concentration of biomarker sample \#1 and 2 of the kits

\begin{tabular}{|c|c|c|c|c|c|}
\hline \multicolumn{2}{|c|}{$\underline{\text { Supplier of biomarkers }}$} & \multirow[t]{2}{*}{ MDD } & \multicolumn{2}{|l|}{ Intra-Assay Precision } & \multirow[t]{2}{*}{ Assayed } \\
\hline A. & Cytokines/Chemokines & & Sample \#1 (CV\%, mean) & Sample \#2 (CV\%, mean) & \\
\hline 1 & Interleukin-1ß (IL-1 B) ${ }^{a}$ & $0.033 \mathrm{pg} / \mathrm{mL}$ & $4.4,0.315 \mathrm{pg} / \mathrm{mL}(\mathrm{n}=20)$ & $3.9,1.30 \mathrm{pg} / \mathrm{mL}(\mathrm{n}=20)$ & singleton \\
\hline 1 & Interleukin-6 (IL-6) ${ }^{a}$ & $0.039 \mathrm{pg} / \mathrm{mL}$ & $6.9,0.436 \mathrm{pg} / \mathrm{mL}(\mathrm{n}=20)$ & $7.8,2.45 \mathrm{pg} / \mathrm{mL}(\mathrm{n}=20)$ & duplicate \\
\hline 2 & Interleukin-12 (IL-12p70) & $2.1 \mathrm{pg} / \mathrm{mL}$ & $5.0,15.85 \mathrm{pg} / \mathrm{mL}(\mathrm{n}=8)$ & $2.13,45.0 \mathrm{pg} / \mathrm{mL}(\mathrm{n}=8)$ & duplicate \\
\hline 1 & IL-1 receptor antagonist & $6.3 \mathrm{pg} / \mathrm{mL}$ & $7.3,66.9 \mathrm{pg} / \mathrm{mL}(\mathrm{n}=20)$ & $5.0,607 \mathrm{pg} / \mathrm{mL}(\mathrm{n}=20)$ & duplicate \\
\hline 2 & Interferon- $\gamma($ IFN- $\gamma)$ & $0.03 \mathrm{IU} / \mathrm{mL}$ & $3.2,1.26 \mathrm{IU} / \mathrm{mL}(\mathrm{n}=20)$ & $3.8,12.28 \mathrm{IU} / \mathrm{mL}(\mathrm{n}=20)$ & duplicate \\
\hline 2 & Tumor Necrosis Factor-a & $3.0 \mathrm{pg} / \mathrm{mL}$ & $5.2,86.7 \mathrm{pg} / \mathrm{mL}(\mathrm{n}=20)$ & $3.7,591 \mathrm{pg} / \mathrm{mL}(\mathrm{n}=20)$ & duplicate \\
\hline 1 & Interleukin-8 (IL-8) ${ }^{a}$ & $0.13 \mathrm{pg} / \mathrm{mL}$ & $5.5,5.5 \mathrm{pg} / \mathrm{mL}(\mathrm{n}=20)$ & 7.3, $37.1 \mathrm{pg} / \mathrm{mL}(\mathrm{n}=20)$ & singleton \\
\hline 1 & CCL3 (MIP-1 a) & $10.0 \mathrm{pg} / \mathrm{mL}$ & $8.9,140 \mathrm{pg} / \mathrm{mL}(\mathrm{n}=20)$ & $8.8,688 \mathrm{pg} / \mathrm{mL}(\mathrm{n}=20)$ & duplicate \\
\hline 1 & CCL4 (MIP-1 $\beta$ ) & $11.0 \mathrm{pg} / \mathrm{mL}$ & 9.0, $51.3 \mathrm{pg} / \mathrm{mL}(\mathrm{n}=20)$ & $3.6,208 \mathrm{pg} / \mathrm{mL}(\mathrm{n}=20)$ & duplicate \\
\hline 1 & CCL5 (RANTES) & $2.0 \mathrm{pg} / \mathrm{mL}$ & $2.5,91.9 \mathrm{pg} / \mathrm{mL}(\mathrm{n}=20)$ & $1.7,573 \mathrm{pg} / \mathrm{mL}(\mathrm{n}=20)$ & duplicate \\
\hline B. & Adipocytokines & & & & \\
\hline 1 & Adiponectin & $0.25 \mathrm{ng} / \mathrm{mL}$ & $2.5,19.8 \mathrm{ng} / \mathrm{mL}(\mathrm{n}=20)$ & $3.4,69.9 \mathrm{ng} / \mathrm{mL}(\mathrm{n}=20)$ & duplicate \\
\hline 1 & Leptin & $7.8 \mathrm{pg} / \mathrm{mL}$ & $3.3,64.5 \mathrm{pg} / \mathrm{mL}(\mathrm{n}=20)$ & $3.0,146 \mathrm{pg} / \mathrm{mL}(\mathrm{n}=20)$ & duplicate \\
\hline C. & Soluble Receptors markers & & & & \\
\hline 1 & sCD14 & $125 \mathrm{pg} / \mathrm{mL}$ & $6.4,1111 \mathrm{pg} / \mathrm{mL}(\mathrm{n}=20)$ & $4.8,2158 \mathrm{pg} / \mathrm{mL}(\mathrm{n}=20)$ & duplicate \\
\hline 1 & sCD25 (sIL-2Ra) & $125 \mathrm{pg} / \mathrm{mL}$ & $6.1,207 \mathrm{pg} / \mathrm{mL}(\mathrm{n}=20)$ & $6.1,613 \mathrm{pg} / \mathrm{mL}(\mathrm{n}=20)$ & duplicate \\
\hline 1 & sCD40L & $10 \mathrm{pg} / \mathrm{mL}$ & $5.1,430 \mathrm{pg} / \mathrm{mL}(\mathrm{n}=20))$ & $4.5,1212 \mathrm{pg} / \mathrm{mL}(\mathrm{n}=20)$ & duplicate \\
\hline 1 & sCD120b (sTNF-RII) & $4.2 \mathrm{pg} / \mathrm{mL}$ & $3.2,68.7 \mathrm{pg} / \mathrm{mL}(\mathrm{n}=20)$ & $2.6,179 \mathrm{pg} / \mathrm{mL}(\mathrm{n}=20)$ & duplicate \\
\hline 1 & sCD126 (slL-6R) & $0.6 \mathrm{pg} / \mathrm{mL}$ & 8.6, $134 \mathrm{pg} / \mathrm{mL}(\mathrm{n}=20)$ & $2.6,644 \mathrm{pg} / \mathrm{mL}(\mathrm{n}=20)$ & singleton \\
\hline 1 & sCD130 (spg130) & $6.5 \mathrm{pg} / \mathrm{mL}$ & $4.3,0.70 \mathrm{ng} / \mathrm{mL}(\mathrm{n}=20)$ & $5.5,1.82 \mathrm{ng} / \mathrm{mL}(\mathrm{n}=20)$ & duplicate \\
\hline 1 & sCD163 & $0.08 \mathrm{ng} / \mathrm{mL}$ & $3.8,20.0 \mathrm{ng} / \mathrm{mL}(\mathrm{n}=20)$ & $3.4,35.1 \mathrm{ng} / \mathrm{mL}(\mathrm{n}=20)$ & duplicate \\
\hline D. & Immune Activation markers & & & & \\
\hline 3 & Neopterin & $2.0 \mathrm{nmol} / \mathrm{L}$ & $7.4,4.5 \mathrm{nmol} / \mathrm{L}(\mathrm{n}=10)$ & $5.6,18.7 \mathrm{nmol} / \mathrm{L}(\mathrm{n}=10)$ & duplicate \\
\hline
\end{tabular}

${ }^{a}$ High sensitivity ELISA; 1: R\&D Systems Inc., USA (A1, B1, C1); 2: Thermo Fisher Scientific, USA (A2); 3: B.R.A.H.M.S., Germany (D3)

Cary, North Carolina) was used for ANOVA to calculate intra-individual, inter-individual, and analytical variance (i.e. between duplicates). The data for each marker were checked for outlier results exceeding $\pm 3 \mathrm{SD}$ from the mean. One data point of SCD40L (week 5) of a subject was ranked as outlier due to a technical problem and excluded from data analysis. All results of the markers fell within the appropriate range of $\pm 2 \mathrm{SD}$ from the mean.

The coefficients of variation $(\mathrm{CV})$ of analytical $\left(\mathrm{CV}_{\mathrm{A}}\right)$, intra-individual $\left(\mathrm{CV}_{\mathrm{I}}\right)$, and inter-individual $\left(\mathrm{CV}_{\mathrm{G}}\right)$ components were calculated according to the approach by Harris and Boyd [29].

The index of individuality (II) is the sample ratio $\mathrm{CV}_{\mathrm{I}}$ to $\mathrm{CV}_{\mathrm{G}}$ and was calculated by the following formula:

$\left.\mathrm{II}=\sqrt{ }\left(\mathrm{CV}_{\mathrm{A}}^{2}+\mathrm{CV}_{\mathrm{I}}^{2}\right) / C \mathrm{CV}_{\mathrm{G}}\right)$ for a majority of the biomarkers and simply by $\mathrm{CV}_{\mathrm{I}} / \mathrm{CV}_{\mathrm{G}}$ for IL-1 $\beta$, IL-8, sIL-6R, and lymphocyte phenotypes [9]. Examining the heterogeneity of within-subject variation for a given biomarker, the index of heterogeneity $(\mathrm{IH})$ was calculated as the observed CV of the set of individuals' variance to the theoretical CV using the formula of:
$\mathrm{IH}=\mathrm{CV}_{\mathrm{T}} / \sqrt{ }(2 /[\mathrm{n}-1])$ where $\mathrm{CV}_{\mathrm{T}}=\sqrt{ } \quad\left(\mathrm{CV}_{\mathrm{A}}{ }^{2}+\mathrm{CV}_{\mathrm{I}}^{2}\right)$ and $\mathbf{n}$ is the average number of observations (samples) per subject. Since the number of samples per subject in our study was 6 , an $\mathrm{IH}<1.58$ indicates that the $\mathrm{CV}_{\mathrm{I}}$ data is homogeneous for a biomarker because the index is $<\{1+$ $\left.2\left[1 /(2 \mathrm{n})^{1 / 2}\right]\right\}[12,26]$. The critical difference or reference change value (RCV) was calculated using the following formula: $\mathrm{RCV}=2^{1 / 2 *} \mathrm{Z} *\left(\mathrm{CV}_{\mathrm{A}}^{2}+\mathrm{CV}_{\mathrm{I}}^{2}\right)^{1 / 2}$ and the Z-score for a probability of $95 \%$ or $p<0.05$ was 1.96 while the Z-score for $p<0.01$ or probability of $99 \%$ was 2.56 (bidirectional).

The reliability coefficient $(\mathrm{R})$ is the ratio of betweensubject variation to total variation. It is another measurement of individuality and calculated as: $\mathrm{R}=\mathrm{CV}_{\mathrm{G}}{ }^{2}$ / $\mathrm{CV}_{\mathrm{A}}^{2}+\mathrm{CV}_{\mathrm{I}}^{2}+\mathrm{CV}_{\mathrm{G}}^{2}$.

The value of $R$ ranged between 0 and 1 . When $\mathbf{R}$ approaches 1 , this means that there is very little intra-individual variation of results over time, while also indicating that great confidence can be placed in a single result with no need for repeat measurement [30].

The analytical imprecision $\left(\mathrm{CV}_{\mathrm{A}}\right)$, bias $\left(\mathrm{B}_{\mathrm{A}}\right)$, and total error allowable $\left(\mathrm{TE}_{\mathrm{a}}\right)$ for each biomarker based on 
biological variation for desirable quality specifications were calculated using the following formulas [11,31]:

Precision: $\mathrm{CV}_{\mathrm{A}}<0.50 \mathrm{CV}_{\mathrm{I}}$

Bias: $\mathrm{B}_{\mathrm{A}}<0.250 \times\left(\mathrm{CV}_{1}^{2}+\mathrm{CV}_{\mathrm{G}}{ }^{2}\right)^{1 / 2}$

Total Error Allowable $\left(\mathrm{TE}_{\mathrm{a}}\right)$ :

For $p<0.05: \mathrm{TE}_{\mathrm{a}}<0.250\left(\mathrm{CV}_{\mathrm{I}}{ }^{2}+\mathrm{CV}_{\mathrm{G}}{ }^{2}\right)^{1 / 2}+1.65\left(0.50 \mathrm{CV}_{1}\right)$

For $p<0.01$ : $\mathrm{TE}_{\mathrm{a}}<0.250\left(\mathrm{CV}_{\mathrm{I}}^{2}+\mathrm{CV}_{\mathrm{G}}{ }^{2}\right)^{1 / 2}+2.33\left(0.50 \mathrm{CV}_{1}\right)$

For biomarkers in which the desirable quality specifications cannot easily be met using general methodology and technology, use of minimum quality specifications would be appropriate, whereas when they are easily met, optimum quality specifications should be used [9].

\section{Additional files}

Additional file 1: Table $\mathbf{S 1 a}+\mathbf{b}$. The mean, median, and inter quartile range (IQR) values of eighteen serum biomarkers (IL-1 $\beta$, IL-6, IL-1 ra, IFN- $\gamma$, TNF-a, IL-8, MIP-1ß, RANTES, Adiponectin, Leptin, sCD14, SCD40L, sCD163, spg 130, sIL-2Ra, sIL-6R, sTNF-RII, and neopterin) and five lymphocyte phenotypes (CD3, CD4, and CD8 T-cell, CD19 B-cell, and CD56/16 NK cell) were calculated and presented for six males, six females, and both genders. (DOCX $18 \mathrm{~kb}$ )

Additional file 2: Table S2. The Spearman's correlation was assessed to determine the relationship among the eighteen serum biomarkers and five lymphocyte phenotypes of 12 subjects with six visits (total of 71 observations for each marker). There were both positive and negative statistically significant $(p<0.05)$ correlation coefficients $(r)$ ranging from very weak to strong as well as instances of no correlation among the biomarkers. (DOCX $18 \mathrm{~kb}$ )

Additional file 3: Figure S1 and Figure S2. There were strong positive correlation coefficients ( $r$ ) between serum levels of IL-1ra and TNF-a $(r=$ $0.65, p<0.001)$, and percentage CD4+ T-cell and CD3 T-cell $(r=0.49, p<$ 0.001 ), a strong negative correlation coefficient between serum levels of sIL-6R and percentage of CD4+ T-cell $(r=-0.65, p<0.001)$, and between percentage of CD56/16 and CD4+ T-cell $(r=-0.58, p<0.001)$. Moderate correlation was seen between serum levels of MIP-1 $\beta$ and SCD14, between serum levels of sIL-2Ra and SCD14, and between serum levels of IFN- $\gamma$ and IL-6, while no correlation was seen between serum levels of sCD40 and CD4+ T-cell. (ZIP $2800 \mathrm{~kb}$ )

Additional file 4: Method of measurement for each serum biomarker, suppliers of assay kits, and clinical and research significance of each biomarker along with their publication references are presented in Additional file 4. (DOCX $36 \mathrm{~kb}$ )

\section{Abbreviations}

APC: Allophycocyanin; BMI: Body Mass Index; BV: Biological variation; $\mathrm{CD}$ : Cluster of differentiation; $\mathrm{CV}$ : Coefficient of variation; $\mathrm{CV}_{\mathrm{A}}$ : Analytical coefficient of variation; $\mathrm{CV}_{\mathrm{G}}$ : Inter-individual coefficient of variation; $\mathrm{CV}_{\text {: }}$ : Intra-individual coefficient of variation; FITC: Fluorescein isothiocyanate; HIV-1: Human immunodeficiency virus type 1; IFN- $\gamma$ : Interferon gamma; IH: Index of heterogeneity; II: Index of individuality; IL-: Interleukin; IL-1Ra: Interleukin-1 receptor antagonist; MDD: Minimum detectable dose; MIP: Macrophage inflammatory protein; PE: Phycoerythrin; PerCP: Peridinin chlorophyll protein; RCV: Reference change value; RCV: Reference change value; SCD40L: soluble CD40 ligand; sgp130: soluble glycoprotein 130; sIL-2Ra: soluble interleukin-2 receptor alpha; sIL-6R: soluble interleukin-6 receptor; sTNF-RII: soluble tumor necrosis receptor II; TNF-a: tumor necrosis receptor alpha

\section{Acknowledgements}

The authors thank Nabil Aziz for data entry and plots, Marianne Chow and Gina Bonifacio for technical support.

\section{Authors' contributions}

NA preformed the serum biomarker assays, drafted the manuscript, and designed the plots; RD helped in the interpretation of data and as well as the critical revision of the manuscript; JQ and DG analyzed and interpreted the data; TR helped in editing and revision of the manuscript; and $A B$ designed the research project and revised the manuscript. All authors have given final approval of the version to be published.

\section{Funding}

This work was supported by grants from the National Institutes of Health (U01-A1-35042); The MACS is funded by the National Institute of Allergy and Infectious Diseases, with additional supplemental funding from the National Cancer Institute (U01-Al35042, 5-M01-RR00722 (GCRC), U01-A135043, U01Al37984, U01-A135039, U01-Al35040, U01-Al37613, and U01-Al35041). This project has been funded in whole or in part with Federal funds from the $\mathrm{Na}$ tional Cancer Institute, National Institutes of Health, under Contract No. N01CO56000. The funding body didn't have any role in the design, collection, analysis, and interpretation of data or in the writing of the manuscript.

\section{Availability of data and materials}

The data used to support the findings of this study are included within the article and more detailed data of the current study are available from the corresponding author on reasonable request.

\section{Ethics approval and consent to participate}

All participants read and signed the informed consent for the blood draw and laboratory tests performed within this study. The study and consent procedure were approved by the ethics committee of the UCLA Institutional Review Boards (IRBs) (IRB\#17-000424). All participants provided their written informed consent to participate in this study. This study was conducted in adherence to the Declaration of Helsinki.

\section{Consent for publication}

Not applicable

\section{Competing interests}

The authors declare that they have no competing interests.

\section{Author details}

'Department of Epidemiology, Fielding School of Public Health at University California Los Angeles (UCLA), 650 Charles E. Young Dr. South, Los Angeles, CA 90095-1772, USA. ${ }^{2}$ David Geffen School of Medicine, UCLA, Los Angeles, California 90095, USA. ${ }^{3}$ Department of Biostatics, Fielding School of Public Health, UCLA, Los Angeles, California 90095-1772, USA. ${ }^{4}$ Department of Intercollegiate Athletes, UCLA, Los Angeles, California 90095-1772, USA.

Received: 12 April 2018 Accepted: 21 August 2019

Published online: 14 September 2019

\section{References}

1. Edlefsen KL, Martinez-Maza O, Madeleine MM, Magpantay L, Mirick DK, Kopecky KJ, La Croix AZ, De Roos AJ. Cytokines in serum in relation to future non-Hodgkin lymphoma risk: evidence for associations by histologic subtype. Int J Cancer. 2014;135(4):913-22.

2. Fahey J. Cytokines, plasma immune activation markers, and clinically relevant surrogate markers in human immunodeficiency virus infection. Clin Diagn Lab Immunol. 1998;5(5):597-603.

3. French MA, Cozzi-Lepri A, Arduino RC, Johnson M, Achhra AC, Landay A. Plasma levels of cytokines and chemokines and the risk of mortality in HIVinfected individuals: a case-control analysis nested in a large clinical trial. AIDS. 2015;29(7):847-51.

4. Han J, Wang Y, Gan X, Song J, Sun P, Dong XP. Serum cytokine profiles of children with human enterovirus 71-associated hand, foot, and mouth disease. J Med Virol. 2014;86(8):1377-85.

5. Ndumbi P, Gilbert L, Tsoukas CM. Comprehensive Evaluation of the Immune Risk Phenotype in Successfully Treated HIV-Infected Individuals. PLoS One. 2015;10(2):e0117039

6. Biancotto A, Wank A, Perl S, Cook W, Olnes MJ, Dagur PK, Fuchs JC, Langweiler M, Wang E, McCoy JP. Baseline levels and temporal stability of 27 multiplexed serum cytokine concentrations in healthy subjects. PLoS One. 2013;8(12):e76091. 
7. Epstein MM, Breen EC, Magpantay L, Detels R, Lepone L, Penugonda S, Bream JH, Jacobson LP, Martinez-Maza O, Brimann BM. Temporal stability of serum concentrations of cytokines and soluble receptors measure across two years in low-risk HIV seronegative men. Cancer Epidemiol Biomark Prev. 2013;22(11):2009-15

8. Manolio T. Novel risk markers and clinical practice. N Engl J Med. 2003; 349(17):1587-9.

9. Fraser $C G$, editor. Biological variation: from principles to practice Washington, DC: AACC Press; 2001

10. Ricos V, Alvarez V, Cava F, Garcia-Lario JV, Hernández A, Jiménez CV, Minchinela J, Perich C, Simón M. Current databases on biological variation: pros, cons and progress. Scand J Clin Lab Invest. 1999;59:491-500.

11. Harris EK. Statistical principles underlying analytic goal-setting in clinical chemistry. Am J Clin Pathol. 1979;72:374-82.

12. Harris EK. Distinguishing physiologic variation from analytic variation. J Chronic Disease. 1970;23:469-80.

13. Ford RP, Mitchell PE, Fraser CG. Desirable performance characteristics utilkity of immunoglobulin and light-chain assays derived from data on biological variation. Clin Chem. 1988;34(9):1733-6.

14. Shand B, Elder P, Scott R, Frampton C, Willis J. Biovariablity of plasma adiponectin. Clin Chem Lab Med. 2006;44:1264-8.

15. González C, Cava F, Ayllón A, Guevara P, Navajo JA, González-Buitrago JM. Biological variation of interleukin-1 beta, interleukin-8 and tumor necrosis factor-alpha in serum of healthy individuals. Clin Chem Lab Med. 2001;39(9):836-41.

16. Cava F, González C, Pascual MJ, Navajo JA, González-Buitrago JM. Biological variation of interleukin 6 (IL-6) and soluble interleukin 2 receptor (sIL2R) in serum of healthy individuals. Cytokine. 2000;12(9):1423-5.

17. Møller HJ, Petersen PH, Rejnmark L, Moestrup SK. Biological variation of soluble CD163. Scand J Clin Lab Invest. 2003;63(1):15-21.

18. Jilma B, Dirnberger E, Löscher I, Rumplmayr A, Hildebrandt J, Eichler HG, Kapiotis S, Wagner OF. Menstrual cycle-associated changes in blood levels of interleukin-6, alpha1 acid glycoprotein, and C-reactive protein. J Lab Clin Med. 1997:130(1):69-75.

19. Brännström M, Fridén BE, Jasper $M$, Norman RJ. Variations in peripheral blood levels of immunoreactive tumor necrosis factor alpha (TNFalpha) throughout the menstrual cycle and secretion of TNFalpha from the human corpus luteum. Eur J Obstet Gynecol Reprod Biol. 1999;83(2):213-7.

20. van den Heuvel MJ, Horrocks J, Bashar S, Taylor S, Burke S, Hatta K, Lewis JE, Croy BA. Menstrual cycle hormones induce changes in functional interactions between lymphocytes and decidual vascular endothelial cells. J Clin Endocrinol Metab. 2005;90(5):2835-42.

21. Aziz N, Nishanian P, Taylor JM, Mitsuyasu RT, Jacobson JM, Dezube BJ, Lederman MM, Detels R, Fahey JL. Stability of plasma levels of cytokines and soluble activation markers in patients with human immunodeficiency virus infection. J Infect Dis. 1999;179(4):843-8.

22. Han Y, Lassen K, Monie D, Sedaghat AR, Shimoji S, Liu X, Pierson TC, Margolick JB, Siliciano RF, Siliciano JD. Resting CD4+ T cells from human immunodeficiency virus type 1 (HIV-1)-infected individuals carry integrated HIV-1 genomes within. Actively transcribed host genes. J Virol. 2004;78(12): 6122-33.

23. Kornbluth RS. The emerging role of CD40 ligand in HIV infection. J Leukoc Biol. 2000;68(3):373-82 Review.

24. Ricós C, Álvarez V, Perich C, Fernández-Calle P, Minchinela J, Cava F, Biosca C, Boned B, Domenech M, Garcia-Lario JV, Simon M, Frenadez PF, DiazGarzon J, Gonzalez-Lao E. Rationale for using data on biological variation. Clin Chem Lab Med. 2015;53(6):863-70.

25. Ross SM, Fraser CG. Biological variation of cardiac markers: analytical and clinical considerations. Ann Clin Biochem. 1998;30:80-4.

26. Fraser CG, Harris EK. Generation and application of data on biological variation in clinical chemistry. Crit Rev Clin Lab Sci. 1989;27(5):409-37.

27. Ricós $C$, Jiménez $C V$, Hernández A, Simón M, Perich C, Alvarez V, Minchinela J, Macia M. Biological variation in urine samples used for analyte measurements. Clin Chem. 1994:40(3):472-7.

28. Schnizlein-Bick C, Mandy F, O'Gorman M, Paxton H, Nicholson J, Hultin L, Gelman R, Wilkening C, Livnat D. Use of CD45 gating in the three and four-color flow cytometric immunophenotyping: Guideline from the National Institute of Allergy and infectious Disease, Division of AIDS. Cytometry. 2002;50:46-52.

29. Harris EK, Boyd JC. Comparison of within-subject and among-subjects variance; Statistical Bases of Reference Values in Laboratory Medicine. New York, N.Y: Marcel Dekker, Inc; 1995. p. 187-221.
30. Young DS, Bermes EW Jr. Preanalytical Variables and Biological Variation Chapter 17. In: TIETZ Textbook of Clinical Chemistry and Molecular Diagnostics 4th Edition. Philadelphia: WB Saunders Co; 2006. p. 470

31. Fraser CG, Hyltoft Petersen P. Desirable standards for laboratory tests if they are to fulfill medical needs. Clin. Chem. 1993;39(7):1447-55.

\section{Publisher's Note}

Springer Nature remains neutral with regard to jurisdictional claims in published maps and institutional affiliations.
Ready to submit your research? Choose BMC and benefit from:

- fast, convenient online submission

- thorough peer review by experienced researchers in your field

- rapid publication on acceptance

- support for research data, including large and complex data types

- gold Open Access which fosters wider collaboration and increased citations

- maximum visibility for your research: over $100 \mathrm{M}$ website views per year

At BMC, research is always in progress.

Learn more biomedcentral.com/submissions 